\title{
Peran Dosen dalam Pembelajaran Pendidikan Pancasila dan Kewarganegaraan untuk Mendukung Program Moderasi Beragama
}

\author{
Koko Adya Winata ${ }^{1}$, Tatang Sudrajat ${ }^{2}$,Yuyun Yuniarsih ${ }^{3}$, Qiqi Yuliati Zaqiah ${ }^{4}$ \\ ${ }^{\mathbf{1 , 2 , 3}}$ Universitas Sangga Buana Bandung Indonesia, ${ }^{4}$ UIN SGD Bandung Indonesia \\ adyawinata@gmail.com,id.tatangsudrajat@gmail.com,yuyunyuniarsih79@gmail.com
}

\begin{abstract}
Abstrak: Penelitian ini mengkaji berkenaan dengan peran dosen dalam pembelajaran pendidikan Pancasila dan PKn untuk mendukung program moderasi beragama. Peran dosen dalam pembelajaran pendidikan Pancasila dan kewarganegaraan menempati posisi yang sangat penting untuk membentuk karakter Mahasiswa agar memiiliki spirit nasionalisme, keragaman dan semangat berkewarganegaraan. Peran dosen sebagai pendidik harus mampu memberikan pemahaman yang baik dan komprehensif kepada Mahasiswa tentang kondisi masyarakat Indonesia yang multicultural. Melalui pembelajaran pendidikan Pancasila dan kewarganegaraan serta program moderasi agama yang baik Mahasiswa diharapkan memiliki pemahaman terhadap nilai-nilai kebangsaan, keberagaman, keadaban, toleransi dan persamaan. Berdasarkan hasil penelitian dapat disimpulkan; 1) Rendahnya minat dan motivasi belajar Mahasiswa terhadap pendidikan Pancasila dan kewarganegaraan; 2) adanya indikasi Mahasiswa yang terpapar ideology khilafah; 3) pembelajaran pendidikan Pancasila dan kewarganegaraan masih belum terintegrasi dengan moderasi agama.
\end{abstract}

Kata Kunci: Peran Dosen, Pendidikan Pancasila dan Kewarganegaraan, Moderasi Agama

Abstract: This study examines the role of lecturers in learning of Pancasila and PKN education to support the religious moderation program. The role of lecturers in learning Pancasila education and citizenship occupies a very important position to shape the character of students in order to have a spirit of nationalism, diversity and a spirit of citizenship. The role of lecturers as educators must be able to provide students with a good and comprehensive understanding of the condition of multicultural Indonesian society. Through learning Pancasila education and citizenship and a good religious moderation program Students are expected to have an understanding of the values of nationality, diversity, civilization, tolerance and equality. Based on the results of the study it can be concluded; 1) The lack of interest and motivation for student learning towards Pancasila education and citizenship; 2) there are indications that students are exposed to the ideology of the caliphate; 3) learning of Pancasila education and citizenship is still not integrated with religious moderation.

Keywords: Role of Lecturers, Pancasila Education and Citizenship, Religious Moderation

\section{Pendahuluan}

Pembelajaran pendidikan Pancasila dan kewarganegaraan merupakan Mata Kuliah Wajib Umum (MKWU) yang harus diajarkan di perguruan tinggi kepada seluruh mahasiswa. Mata kuliah pendidikan Pancasila termasuk mata kuliah pengembangan kepribadian sebagimana halnya mata kuliah kewarganegaraan ( PKN ), Agama dan bahasa berdasarkan susunan kurikulum inti perguruan tinggi. Dalam Peraturan Pemerintah No. 19 tahun 2005 tentang Standar Nasional Pendidikan yang menetapkan kurikulum tingkat Satuan Pendidikan Tinggi wajib memuat mata kulian pendidikan agama, pendidikan 
Kewarganegaraan dan Bahasa Indonesia serta Bahasa Inggris. Peraturan tersebut merupakan penjabaran dan pengejawantahanan terhadap UU Nomor 20 Tahun 2003 tentang Sistem Pendidikan Nasional. Landasan yuridis yang menjadi pijakan terhadap pelaksanaan pendidikan Pancasila di perguruan tinggi adalah Surat Edaran Dirjen Dikti No 914/E/T/2011. Dalam salah satu keputusannya menegaskan tentang perlunya revitalisasi Pancasila. Setiap perguruan tinggi diharapkan dapat melakukan berbagai kajian dalam upava pembudayaan Pancasila dan implementasinya dalam berbagai peraturan dan mata kuliah yang relevan, sehingga tercipta suasana akademis yang maju berdasarkan pada niai-nilai Pancasila.

Implementasi pembelajaran pendidikan Pancasila dan kewarganegaraan di perguruan tinggi sangat tergantung kepada dosen dalam menyusun rencana pembelajaran dan tujuan pembelajaran. Proses pembelajaran pendidikan Pancasila dan kewarganegaraan tidak terlepas dari peran dosen dalam merumuskan tujuan pembelajaran dan pemilihan model pembelajaran. Model dan metode pembelajaran yang dipilih harus dapat mengembangkan potensi Mahasiswa dan memotivasi minat belajar Mahasiswa terhadap pendidikan Pancasila dan kewarganegaraan. Kedudukan Pendekatan atau metode dan model pembelajaran berfungsi sebagai alat untuk menyampaikan materi pelajaran kepada Mahasiswa terkait nilai-nilai Pancasila dan kewarganegaraan. Penggunaan pendekatan pembelajaran merupakan salah satu factor yang sangat menentukan terhadap suksesnya pembelajaran. Melalui pendekatan pembelajaran yang tepat, pembelajaran pendidikan Pancasila dan kewarganegaraan dapat dipahami Mahasiswa secara baik, benar dan efektif. Mahasiwa diharapkan dapat mengembangkan aspek pengetahuannya (cognitif skill), kesadaran akan pentingnya nilai-nilai Pancasial (afektif skill) dan dorongan untuk mengamalkan Pancasila dalam kehidupan sehari-hari (conatif skill).

Peran Dosen Pancasila dan kewarganegaraan harus dapat menumbuhkan dan membangun karakter Mahasiswa yang berkepribadian Pancasila dalam segala aspeknya baik pandangan, pemikiran, sikap dan prilaku kehidupannya. Keberhasilan dosen dalam pembelajaran pendidikan Pancasila dan kewarganegaraan sangat terkait dengan kompetensi yang dimilikinya. Dosen yang memiliki kompetensi yang baik akan mudah dalam melaksanakan proses pembelajaran dan tujuan pembelajaran pun dapat tercapai sesuai dengan yang sudah ditentukan dalam perencanaan. Dosen kompeten mampu menciptakan lingkungan belajar yang efektif, menyenangkan, dan mampu mengelola kelasnya, sehingga belajar siswa berada pada tingkat optimal. Variabel kompetensi dalam konteks pembelajaran merupakan keharusan untuk dimiliki oleh seorang dosen dalam upaya membantu mahasiswa memperoleh prestasi belajar (Yuli Alam, 2017: 24). Peran dosen Pancasila dan kewarganegaraan dapat dilihat dari proses pembelajaran ketika mengelola kelas dengan mengintegrasikan Mata kuliah Pancasila dan mata kuliah Agama. Dosen Pancasila dan PKN harus bersinergi dengan dosen Agama seiring dengan munculnya paham radikal di kalangan Mahasiswa yang mengatasnamakan Agama.

Adanya indikasi Mahasiswa yang terpapar ideology khilafah, radikalisme dan fundamentalisme merupakan tantangan tersendiri dalam proses pembelajaran pendidikan Pancasila dan kewarganegaraan. Mantan Menhan Ryamizard memaparkan, sekitar 23,4 persen mahasiwa setuju dengan jihad dan memperjuangkan negara Islam atau Khilafah, sedangkan di tingkat SMA sekitar 23,3 persen. Sementara itu 18,1 persen pegawai swasta memgatakan tidak setuju dengan ideologi Pancasila, 19,4 persen PNS dan 9,1 pegawai BUMN (detik com, 10/7/2019). Oleh sebab itu, dosen Pancasila harus memiliki kemampuan 
menggunakan pendekatan agama dalam proses kegiatan belajar mengajarnya. Melalui model pembelajaran integrasi materi Pancasila, PKN dan moderasi Agama diharapkan dapat menanggulangi pemikiran dan ideologi khilafah yang berkembang di kampus. Gerakan pemikiran radikalisme, pundamentalisme dan ideology khilafah di kalangan Mahasiswa dapat lebih awal terdeteksi dan diluruskan sesuai konsep yang sebenarnya.

\section{Metode Penelitian}

Metode penelitian yang dipergunakan dalam penelitian ini adalah metode kualitatif dengan pendekatan library research. Penelitian kepustakaan artinya, peneliti menggunakan literatur (kepustakaan), baik berupa buku, catatan, dokumen, jurnal dan laporan hasil penelitian sebelumnya. Penelitian juga dilakukan dengan melakukan pengamatan di kampus dan pengalaman peneliti sebagai dosen pendidikan Pancasila dan kewarganegaraan. Dalam penelitian kualitatif unsur kecermatan dan langkah yang sistematis memegang peranan sangat penting. Dengan menggunakan pendekatan kualitatif diharapkan peneliti dapat lebih leluasa dalam memahami, mengamati, mencermati dan menganalisis serta melakukan penelaahan lebih akurat berkenaan dengan peran dosen dalam pembelajaran pendidikan Pancasila dan kewarganegaraan untuk mendorong program moderasi beragama. Dalam hal ini peneliti akan mengkaji dan meneliti secara objektif tentang bagaimana konseptualiasi peran dosen dalam pembelajaran pendidikan Pancasila dan kewarganegaraan untuk mendorong program moderasi beragama. Dan bagaimana implementasinya seiring dengan adanya indikasi Mahasiswa yang terpapar dengan ideology khilafah, radikalisme dan pundamentalisme.

\section{Hasil dan Pembahasan}

\section{Peran Dosen Pancasila dan Kewarganegaraan}

Dosen adalah pendidik professional yang menempati posisi strategis di dalam proses pembelajaran di perguruan tinggi. Dosen bertugas untuk mentrasformasikan ilmu pengetahuan, meneliti, mengembangkan dan mengabdikan ilmunya untuk kepentingan masyarakat. Tugas umum dosen adalah mendidik, mengajar dan memahamkan Mahasiswa terhadap materi perkuliahan melalui proses pembelajaran yang sudah ditetapkan. Berdasarkan Undang-undang RI Nomor 14 tahun 2005 tentang Guru dan Dosen adalah sebagai berikut: "Guru dan Dosen adalah pendidik professional dengan tugas utama mendidik, mengajar, membimbing, mengarahkan, melatih, menilai dan mengevaluasi mahasiswa pada pendidikan anak usia dini jalur pendidikan formal, pendidikan dasar, dan pendidikan menengah dan pendidikan berkelanjutan". Peran dosen sangat terkait dengan TUPOKSI yang diembannya untuk diimplemtasikan dalam proses pembelajaran. Dosen yang menjalankan TUPOKSInya dengan baik, maka dosen tersebut telah melaksanakan perannya sebagai pendidik profesional, pelatih, penguji dan pembimbing mahasiswanya. Untuk mewujudkan perannya tersebut dosen harus memiliki kemampuan dalam merencanakan proses pembelajaran.

Dosen dapat melakukan berbagai cara dalam mengajar, seperti memberi petunjuk, membujuk, mendorong, membimbing, menunjuk, berbicara, memerintah, memberitahu, menceritakan, menyampaikan materi, mendemonstrasikan, melatih, menguji, meneliti, mengkritik, mengoreksi, mengarahkan, mengasah keterampilan, serta hal lain yang tidak menghambat pemahaman Mahasiswa (Didi Supriadie, dkk, 2012: 11). Dosen Pancasila dan PKN harus mampu merencanakan pembelajaran, mengelola kelas dan menentukan tujuan 
pembelajaran. Proses pembelajaran akan berlangsung menyenangkan dan komunikatif sangat tergantung dari peran dosennya. Pembelajaran pendidikan Pancasila dan kewarganegaraan akan berlangsung efektif manakala dosennya mampu mengelola kelas dengan baik.

Dosen Pancasila dan kewarganegaraan adalah pendidik yang harus memiliki kemampuan untuk mengembangkan potensi Mahasiswa yang mencakup beberapa hal :

a. Pengetahuan kognitif Mahasiswa terhadap pendidikan Pancasila dan PKN

Pengetahuan kognitif adalah salah satu ranah yang menjadi penilaian terpenting dalam proses pembelajaran. Pengetahuan kognitif terdiri dari enam tahapan yaitu ingatan, pemahaman, penerapan, analisis, evaluasi dan menciptakan. Pengetahuan kognitif merupakan kemampuan pengetahuan Mahasiswa terhadap materi pembelajaran. Pengetahuan itu terdiri atas empat tingkatan yaitu pengetahuan faktual, pengetahuan konseptual, pengetahuan prosedural, dan pengetahuan metakognitif (Friska Octavia Rosa, tth: 110) Ranah kognitif merupakan dasar bagi kemampuan Mahasiswa untuk berpikir, memahami, menganalisa dan mengembangkan pengetahuan terkait Pancasila dan kewarganegaraan. Peran dosen memberikan pemahaman terhadap Mahasiswa berkenaan dengan Pancasila seperti, sejarah lahirnya Pancasila, rumusan lahirnya Pancasila, Pancasila sebagai ideology negara, Pancasila sebagai falsafah negara, Pancasila sebagai jati diri bangsa dan Pancasila sebagai alat pemersatu bangsa, Pancasila sebagai sumber hukum dalam melangsungkan ketatanegaraan dan Pancasila sebagai sumber nilai bangsa. Dalam ranah kognitif pembelajaran pendidikan kewarganegaraan dosen berperan untuk memahamkan Mahasiswa mengenai konsep integrasi nasional, identitas nasional, ketahanan nasional, hak dan kewajiban warga negara, pembangunan nasional, demokrasi Pancasila, bela negara dan wawasan nusantara.

b. Pengetahuan afektif Mahasiswa terhadap pendidikan Pancasila dan PKN.

dosen pendidikan Pancasila dan kewarganegaraan adalah mengembangkan pengetahuan afektif mahasiwa terhadap Pnacasila dan PKN. Pengetahuan afektif merupakan pengetahuan kesadaran dan emosi Mahasiswa terhadap pembelajaran Pancasila dan PKN yang akan mendorong terhadap minat belajar. Sehingga Mahasiswa terlibat aktif dalam proses pembelajaran. Mahasiswa mempunyai minat untuk belajar dengan aktif dan menyadari pentingnya pendidikan Pancasila dan PKN sebagai landasan ideology bangsa. Adapun target dari domain afektif meliputi ketekunan, ketelitian, dan kemampuan memecahkan masalah logis dan sistematis terkait dengan materi pembelajaran pendidikan Pancasila dan PKN. Pengetahuan afektif mengembangkan prilaku Mahasiswa berkenaan dengan minat, sikap, nilai, apresiasi dan penyesuaian terhadap proses pembelajaran pendidikan Pancasila dan kewarganegaraan. Domain afektif merupakan ranah yang ditunjukkan oleh perilaku yang berurusan dengan hal-hal emosional seperti perasaan, nilai-nilai, minat, kepedulian, motivasi, dan sikap. Menurut Karthwohl ranah afektif yang muncul meliputi perilaku yang berhubungan dengan hal-hal emosional berdasarkan kategori berupa: menerima, menanggapi, menghargai, konseptualisasi nilai (organisasi), dan internalisasi nilai (karakterisasi) (Riskan Qadar, 2015: 2).

c. Pengetahuann konatif mahasiwa terhadap pendidikan Pancasila dan PKN.

Pengetahuan konatif merupakan kesiapan seseorang untuk berperilaku sesuai dengan pengetahuan, pengalaman dan pemahaman terhadap objek yang diketahui dan diyakininya. Ranah konatif sangat berhubungan dengan objek sikap sesorang untuk 
bertindak dan melakukan sesautu baik menolak atau menerima. Sikap adalah kemampuan menerima atau menolak obyek berdasarkan penilaian terhadap obyek tersebut. Sikap berupa kemampuan menginternalisasi dan eksternalisasi nilai-nilai. sikap itu berfungsi sebagai "dynamic forces" yaitu sebagai kekuatan yang akan menggerakan orang untuk melakukan tindakan (Arvi Riwahyudin, 2015: 12). Pengetahuan konatif Mahasiswa terhadap pendidikan Pancasila dan kewarganegaraan dapat termanifestasikan dalam tindakan dan prilaku Mahasiswa yang berkepribadian Pancasila. Pengetahuan terhadap Pancasila dan kewarganegaraan telah menginternalisasi menjadi sebuah pandangan dan prilakunya. Pengetahuan konatif telah merubah paradigma berfikir Mahasiswa bahwa Pancasila dan kewarganegaraan tidak hanya sebatas ilmu pengetahuan namun sebagai konsep prilaku, nilai hidup dan pandangan hidup bangsa Indonesia yang harus dipertahankan dan diajarkan kepada generasi berikutnya. Kelangsungan hidup negara dan bangsa Indonesia di era globlalisasi, mengharuskan kita untuk melestarikan nilai-nilai Pancasila, agar generasi penerus bangsa tetap dapat menghayati dan mengamalkannya dan agar intisari nilai-nilai yang luhur itu tetap terjaga dan menjadi pedoman bangsa Indonesia sepanjang masa (Ambiro Puji Asmaroini, 2017: 51).

\section{Pembelajaran Pancasila dan Kewarganegaraan}

Pembelajaran pendidikan Pancasila dan PKN merupakan usaha sadar yang dilakukan oleh dosen di perguruan tinggi untuk menyiapkan dan menanamkan mahasiwa agar memiliki pengetahuan, pemahaman dan penghayatan terhadap nilai-nilai Pancasila dan kewarganegaraan. Pancasila sebagai pandangan hidup dan sumber nilai bangsa Indonesia tidak bisa dipisahkan dengan setiap aspek kehidupan berbangsa dan bernegara. Bangsa yang tidak memiliki pandangan hidup maka bangsa tersebut tidak memiliki jati diri bangsa yang akan mudah hanyut diterpa gelombang arus globalisasi. Seluruh warga negara harus menjadikan Pancasila sebagai dasar falsafah negara yang menjadi sumber bagi segala sikap dan tindakannya. Kedudukan Pancasila sebagai sumber nilai dalam pelaksanaan kenegaraan yang menjiwai pembangunan nasional dalam bidang politik, ekonomi, sosial-budaya, dan pertahanan keamanan. Pancasila merupakan jati diri bangsa disebabkan karena nilai-nilai yang terkandung dalam Pancasila merupakan nilainilai luhur yang telah lama ada dan hidup dalam masyarakat Indonesia. Nilai-nilai Pancasila merupakan nilai-nilai kearifan lokal milik bangsa Indonesia sendiri (Abdul Halim, dkk, 2019: 204).

Pembelajaran pendidikan Pancasila dan kewarganegaraan dapat berlangsung efektif manakala dosen memiliki kompetensi yang baik. Kompetensi dosen merupakan kemampuan, keterampilan, keahlian dan sikap seorang pendidik untuk menunjang terhadap pelaksanaan tugasnya agar tujuan pembelajaran dapat tercapai secara optimal. Kompetensi dosen sangat berpengaruh terhadap efektif tidaknya proses pembelajaran. Menurut Hornby, kompetensi adalah orang yang memiliki kesanggupan, kekuasaan, kewenangan, keterampilan, serta pengetahuan untuk melakukan apa yang diperlukan (competence is person having ability, power, authority, skill, knowledge to do what is needed) (Achmad Habibullah, 2012: 363). Dosen yang kompeten tercermin dari kemampuannya dalam mengelola kelas agar proses pembelajaran berlangsung komunikatif.

Kompetensi dosen adalah kemampuan (baik pengetahuan, sikap dan keterampilan) yang harus dimiliki oleh seorang dosen untuk melaksanakan dan mempertanggungjawabkan tugastugasnya sesuai dengan petunjuk yang telah ditetapkan. Mengacu pada Undang-Undang RI No. 14 Tahun 2005 tentang guru dan dosen, untuk dapat menjadi dosen yang profesional seseorang 
harus memiliki empat kompetensi yakni kompetensi pedagogik, kompetensi kepribadian, kompetensi sosial dan kompetensi professional (Mochamad Hatip, dkk, 2018: 113). Kompetensi dosen Pancasila dan PKn merupakan kemampuan dalam merencanakan pembelajaran, melaksanakan pembelajaran, mengelola kelas dan memotivasi minat belajar Mahasiswa terhadap pendidikan Pancasila dan kewarganegaraan. Kompetensi dosen Pancasila dan PKn dapat mendorong minat belajar Mahasiswa untuk bersungguh-sungguh terhadap pendidikan Pancasila dan kewarganegaraan. Mahasiswa akan termotivasi dalam setiap proses pembelajaran sehingga ada rasa tanggung jawab untuk mengetahui dan memahami terhadap materi pembelajaran pendidikan Pancasila dan kewarganegaraan. Kompetensi yang harus dimiliki oleh dosen Pancasila dan kewarganegaraan (PPKn) adalah:

1. Kemampuan Pedagogik dosen Pancasila dan PKN adalah kemampuan mengelola pembelajaran yang meliputi kemampuan:

a. Merancang, mengelola, dan menilai pembelajaran terkait dengan materi pembelajaran pendidikan Pancasila dan kewarganegaraan.

b. Mampu memahami karakteristik mahasiwa sehingga model pemebelajaran yang digunakan dapat menunjang terhadap kemudahan Mahasiswa dalam menerima materi pembelajaran PPKn.

c. Menerapkan teori belajar dan metode pembelajaran yang dapat mendorong minat belajar Mahasiswa terhadap PPKn.

d. Mampu mengelola pembelajaran PPKn yang berlangsung secara interaktif, inspiratif dan komunikatif.

e. Mampu menggali potensi Mahasiswa dengan memberikan ruang kreatifitas dan kemandirian dalam proses pembelajaran berlangsung sehingga materi pelajaran Pancasila dan kewarganegaraan menjadi pengetahuan konseptual dan factual Mahasiswa.

2. Kemampuan kepribadian adalah kemampuan dosen Pancasila dan kewarganegaraan yang melekat dalam dirinya terkait attitude dan sikap. Dalam hal ini dosen PPKn memiliki kemampuan:

a. Kepribadian dosen yang konsisten terhadap norma agama, social, budaya dan hukum yang berlaku.

b. Kepribadian dosen untuk senantiasa menjungjung tinggi prilaku yang mencerminkan akhlak yang mulia, baik di kampus maupun di luar kampus.

c. Kepribadian dosen untuk mempunyai rasa tanggung jawab yang tinggi terhadap profesi sebagai pendidik.

3. Kemampuan Sosial adalah kemampuan dosen Pancasila dan kewarganegaraan yang meliputi kemampuan;

a. Kemampuan berkomunikasi baik secara lisan, tulisan atau isyarat yang sangat penting dalam menunjang proses pembelajaran PPKn.

b. Kemampuan mengunakan teknologi komunikasi dan informasi secara fungsional untuk mengefektikan proses pembelajaran PPKn.

c. Kemampuan bergaul secara efektif dengan Mahasiswa dalam upayanya untuk mencapai tujuan pembelajaran.

4. Kemampuan profesional adalah kemapuan dosen Pancasila dan PKn yang meliputi:

a. Kemampuan penguasaan materi pembelajaran secara luas dan mendalam terkait dengan Pancasila dan PPkn. 
b. Kemampuan mengatasi persoalan yang timbul dari dalam dan luar Mahasiswa terkait dengan materi pembelajaran PPKn.

c. Kemampuan untuk melaksanakan penelitian dan pengabdian terhadap masyarakat terkait aktualisasi nilai-nilai Pancasila dan kewarganegaraan.

d. Kemampuan untuk memahami isu-isu yang berkembang di masyarakat yang dipandang akan mengancam terhadap nilai-nilai Pancasila seperti pemikiran dan gerakan radikalisme, fundamentalisme, komunisme dan ideology khilafah.

Kompetensi tersebut harus dimiliki oleh dosen Pancasila dan kewarganegaraan untuk memaksimalkan perannya sebagai pendidik dalam rangka menjaga, melestarikan dan mewariskan nilai-nilai Pancasila dan kewarganegaran kepada Mahasiswa dan generasi berikutnya. Variable kompetensi dalam konteks pembelajaran merupakan keharusan untuk dimiliki oleh seorang dosen dalam upaya membantu mahasiswa memperoleh prestasi belajar. Dengan kompetensi yang baik Mahasiswa dapat termotivasi dan terdorong minat belajarnya terhadap materi pelajaran Pncasila dan PPKn. Motivasi belajar mahasiswa merupakan faktor yang dapat member dampak terhadap prestasi belajar. Jika seorang mahasiswa memiliki motivasi belajar tinggi, maka ia akan terdorong untuk selalu belajar yang pada akhirnya dapat menghasilkan prestasi belajar yang baik (Yuli Alam, 2018: 25). Mahasiswa diharapkan dapat memiliki pengetahuan kognitif, afektif dan konatif tercermin dalam sikap dan prilakunya yang berkepribadian Pancasila.

\section{Munculnya Ideologi Khilafah}

Gerakan Khilafah Islamiyah ini sudah terjadi sejak tahun 90-an hingga saat ini. Mereka berpendapat bahwa ditegakkannya Khilafah Islam di Indonesia dengan pemimpin yang disebut Khalifah maka akan menjadikan pemerintahan ini adil dan sejahtera karena mereka menganggap bahwa Khalifah adalah wakil Allah yang diturunkan ke bumi untuk memimpin seluruh penjuru dunia. Tujuan Hizbut Tahrir Indonesia yang ingin mendirikan sistem Khilafah Islam adalah untuk menyampaikan kebebasan dalam berpendapat pada ranah pemerintahan bernegara (Baidhowi, 2016: 499) Khilafah adalah sistem politik yang lahir dengan latar belakang kesukuan yang sangat kental. Kekentalan semangat kesukuan ini dicairkan dalam bentuk politik yang berawal di saat Nabi Muhammad SAW diutus. Khilafah yang dibawa oleh Rasulullah SAW adalah sistem politik yang yang didasarkan pada semangat menjadikan suku, bukan sebagai akhir dari sistem politik akan tetapi awal dari perjalanan pengabdian untuk masyarakat yang lebih luas. Sedangkan semangat Khilafah yang ingin ditegakkan saat ini masih sangat banyak bertumpu pada sistem Khilafah yang sudah dikooptasi semangat kesukuan daripada anti kesukuan (Komaruddin Hidayat, 2014: 19). Kelompok yang mengembangkan ideology khilafah adalah Hizbuth TharirIndonesia (HTI).

Menurut pandangan dan keyakinan kelompok Hizbut Tahrir Indonesia, Khilafah Islam adalah sebuah solusi yang membawa kesejahteraan masyarakat Indonesia, mereka meyakini bahwa dengan ditegakkannya Khilafah Islam di Indonesia adalah sebuah jawaban dari persoalan yang dialami oleh masyarakat Indonesia saat ini. Negara tanpa khilafah akan berada dalam keterpurukan karena berada dalam system yang membiarkan kedholiman. Bagi kelompok penganut Khilafah Islam, negara tanpa khilafah akan berdampak pada tiga masalah utama yang harus dihadapi oleh umat Islam saat ini: (Mohammad Mahfud MD, 2017: 138)

1. Kehilangan kepemimpinan umum di tengah-tengah umat Islam, sehingga umat Islam mudah terpecah belah. 
2. Umat dipandang akan susah menjalankan penegakan hukum agama secara menyeluruh (kaffah) yang bisa karena tidak adanya institusi legal sebagai eksekutor (Khilafah).

3. Tanpa adanya Khilafah umat Islam akan lalai dalam menjalankan perintah utamanya, yakni berdakwah ke seluruh penjuru duni

Khilafah adalah sebuah pilihan untuk penegakan keadilan yang selama ini masih jauh dari kenyataan. Ada beberapa hal yang menjadi penyebab munculnya gerakan ideology khilafah:

\section{a. Pengaruh globalisasi.}

Globalisasi merupakan sebuah istilah yang memiliki hubungan dengan peningkatan keterkaitan dan ketergantungan antarbangsa dan antarmanusia di seluruh dunia melalui perdagangan, investasi, perjalanan, budaya populer, dan bentuk-bentuk interaksi lainnya, sehingga batas batas suatu negara menjadi semakin sempit. Globalisasi sebagai sebuah gejala tersebarnya nilai-nilai dan budaya tertentu keseluruh dunia (sehingga menjadi budaya dunia atau world culture) (Donny Ermawan T, 2017). Globalisasi telah mengubah pola pikir dan pola sikap manusia dalam berinteraksi dengan sesama. Akses terhadap teknogi internet memudahkan setiap orang untuk melihat dan mengamati perkembangan yang terjadi di belahan dunia.

Hizb at-Tahrir (HT) yaitu Pemeran utama penegak Khilafah Islam di negaranegara yang berbasis Islam di seluruh dunia. Hizb at-Tahrir Tahrir (HT) didirikan pada tahun 1953, di Al Quds Palestina (Muhammad Rikza Muqtada, Juni 2018: 4). Para penegak Khilafah Islam khususnya Hizb At-Tahrir (HT), Di Indonesia dikenal dengan Hizbut Tahrir Indonesia (HTI). Hizbut Tahrir (HT) masuk ke Indonesia pada tahun 1980 yang dipimpin oleh Abdul Rahman Al-Baghdadi dan memperkenalkan namanya sebagai Hizbut Tahrir Indonesia (HTI) pada tahun 2000. Hizbut Tahrir Indonesia (HTI) sangat antusias untuk menegakkan Khilafah Islam di Indonesia karena melihat Indonesia sebagai negara yang berpenduduk mayoritas Islam. Populasi penduduk yang mayoritas Islam diyakini dapat mudah menerima ideologi khilafah. Gerakan ideology khilafah sangat terbantu proses sebaran ideologinya dari pengaruh globalisasi. Kelompok ideology khilafah sangat berkeinginan bahwa ideology khlafah dapat tersebar dan dipahami oleh masyarakat dunia khususnya kaum muslimin. Sistem khilafah merupakan system pemerintahan yang akan mengatur pola dan prilaku manusia di dunia berdasarkan khilafah Islamiyah yang tidak dibatasi dengan kenegaraan dan kebangsaan. Sistem Khilafah adalah sistem pemerintahan yang khas, yaitu pemerintahan yang berlaku bagi seluruh umat Islam di penjuru dunia untuk menegakkan hukum-hukum syari'at Islam dan mengemban dakwah Islam segenap di berbagai penjuru dunia. Sistem Khilafah berbeda dengan sistem pemeritahan yang lain seperti monarki, republik, kekaisaran, maupun federasi (Indra Utama Tanjung,2018: 116).

\section{b. Digitalisasi Agama.}

Era digital merupakan kondisi dimana setiap orang dapat mengakses berbagai infomasi dalam jaringan (daring). Berbagai informasi di era ini tersedia secara bebas di dunia maya yang memudahkan siapa saja untuk mengaksesnya tanpa batas ruang dan waktu. Dunia menjadi tidak ada sekat sama sekali setalah ditemukannya sistem digital (Shulhan Alfinnas, 2018: 804) Di zaman digital orang belajar agama tidak seperti zaman dahulu yang harus mondok di pesantren bertahun-tahun kepada seorang kiyai yang dipandang memiliki kemapuan terhadap materi agama mulai dari fiqih, nahwu shorof, akhlak, hadist dan tafsir serta yang lainnya. 
Saat ini orang belajar agama bisa melalui smart phone dengan berbagai aplikasi yang telah disediakan baik website, yutube, whats up dan aplikasi lain yang terkait dengan kemudahan teknologi di zaman digital. Kemudahan itu dapat berdampak terhadap mudahnya seseorang untuk belajar agama tanpa ada batasan waktu, tempat dan pigur kiyai yang sesungguhnya. Namun di sisi lain dapat berdampak negative ketika website atau yutube yang dipilih mengajarkan pemahaman agama yang berpandangan radikal. Orang awam akan mudah terdoktrinasi dengan narasi-narasi ceramah atau diskusi agama yang mengatasnakaman agama Islam sekalipun sudah jauh keluar dari nilai-nilai Islam, seperti mengajarkan faham radikal, kebencian dan jihad.

\section{c. Tafsir Tekstual.}

Memahami agama harus betul-betul bersumber kepada orang yang memiliki kemampuan beragama, seperti keilmuannya, keistiqomahannya, kejuhudannya dan akhlaknya. Alquran sebagai kitab suci dan pedoman kaum muslimin memiliki banyak kandungan yang memerlukan penafsiran yang komprehensif. Di dalam Alquran, misalnya ada banyak ayat yang menjelaskan kata jihad setidaknya ada 37 kata jihad yang disebut dengan menggunakan bentuk kata kerja, sifat dan subyek. Ketika memahami makna jihad secara tekstual maka maknanya bisa berbahaya dan seolah-olah Alquran mengajarkan perang tanpa aturan dan norma. Pemahaman keagamaan merupakan bagian penting dari kekerasan agama (radikalisme-terorisme) yang dilakukan. Oleh sebab itu harus dipikirkan kembali pendidikan agama yang bersifat transformatif dan pembebasan pada umat manusia. Pendidikan agama tidak hanya mengajarkan persoalan jihad dalam makna kekerasan atau perang tetapi jihad dalam makna yang luas. (Zuly Qodir, 2016:430).

\section{d. Ketidakadilan Rezim}

Rezim yang sedang berkuasa dipandang merepresentasikan dari sebuah system dan ideology negara yang menjadi landasan dalam menjalankan roda pemerintahan atau kekuasaannya. Kebijakan rezim yang dianggap tidak adil dapat menjadi alasan bagi sebagian kelompok untuk menyalahkan ideology Pancasila dan berharap diganti dengan ideology lain, komunis, ideology khilafah dan ideology lain yang diyakini dapat merealisasikan harapan masyarakat terhadap keadilan diberbagai kehidupan. Kelompok ini melakukan propaganda politik yang sangat intens baik melalui media social, tulisan dan seminar bahkan melalui rekrutmen anggota langsung dengan janji-janji ekonomi yang lebih baik. Misalnya, kelompok ghafatar, keraton agung sejagat dan sunda empire. An ideology khilafah. Gerakan ini termasuk gerakan social dan politik yang menunjukkan ketidak puasan terhadap rezim dalam tatanan politik, ekonomi dan sosial.

Ketidakadilan rezime yang sedang berkuasa telah menjadi alasan kuat untuk melakukan propaganda politik kepada Mahasiswa dan masyarakat. Hizbut Tahrir Indonesia (HTI) sangat berambisi untuk melakukan gerakan Khilafah Islam di Indonesia karena menurut mereka jika Khilafah Islam menjadi sistem pemerintahan di Indonesia dapat menjadi solusi atas jawaban dari masalah-masalah di Indonesia saat ini karena saat ini umat Islam dihadapkan kepada problematika keterpurukan (Nilda Hayati, 2017:182). Motivasi Hizb At-Tahrir Indenesia (HTI) dalam menegakkan Khilafah Islamiyah adalah atas dasar Al-Qur'an Surah An-Nur: 55. Artinya: "Allah telah menjanjikan kepada orang-orang di antara kamu yang beriman dan yang mengerjakan kebajikan, bahwa Dia sungguh sungguh akan menjadikan mereka berkuasa di bumi sebagaimana Dia telah menjadikan orang-orang orang-orang sebelum mereka berkuasa, dan sungguh Dia akan 
meneguhkan bagi mereka dengan agama yang telah Dia ridhai. Dan Dia benar-benar mengubah (keadaan) mereka, setelah berada dalam ketakutan menjadi aman sentosa. Mereka (tetap) menyembah-Ku dengan sesuatu pun. Tetapi barang siapa (tetap) kafir setelah (janji) itu, maka mereka itulah orang-orang yang fasik."

\section{e. Konflik Ideologi.}

Disadari atau pun tidak bahwa media social sudah sangat sering memberitakan informasi tentang fenomena para elite politik yang sedang berancang-ancang untuk meletakan ideology yang berlawanan dengan ideology Pancasila. Pernyataan elite politik yang mengatakan aku bangga jadi anak PKI telah memunculkan banyak tafsir di masyarakat maupun di sebagian lingkungan akademisi. Sikap dan pernyatan elite politik tersebut dipandang sebagai indikasi adanya gerakan politik terselubung dari elite politik untuk menghidupkan kembali ideology komunis. Pada saat yang sama, ada kelompok lain yang berkeinginan untuk mengembangkan ideology khilafah di masyarakat termasuk di kalangan kampus. Khilafah merupakan bagian dari mabda yang harus diwujudkan. Maka dari itu, tegaknya al-dawlah al-islamiyah bergantung pada mabda "Islam. Mabda"e adalah sebutan lain dari ideologi, sebutan mabda ${ }^{e e}$ biasa digunakan oleh kalangan islamisme. Mabda" terdiri dari dua unsur yakni fikrah dan thariqah. Fikrah adalah solusi pemecahan terhadap problematika yang dihadapi oleh manusia, sedangkan thariqah adalah cara melaksanakan dan menjaga ideologi atau mabda (Ainur Rofiq Al-Amin, 2012: 117).

\section{Integrasi Materi Pendidikan Pancasila, Kewarganegaraan dan Moderasi Beragam}

Moderasi beragama adalah sebuah pandangan atau sikap yang selalu mengedepankan pertengahan dalam mengambil sikap terhadap disvaritas atau perbedaan yang ada di masyarakat. Bersikap dengan senantiasa berusaha mengambil posisi tengah dari dua sikap yang berseberangan dan berlebihan merupakan sikap moderasi beragama. Salah satu dari kedua sikap yang ada tidak mendominasi dalam pikiran dan sikap seorang muslim yang moderat. Islam mengajarkan sikap saling menghormati, toleransi dan menjunjung tinggi nilai-nilai kemanusiaan dan keadaban. Islam dipersepsikan mengandung ajaran-ajaran moderat di dalamnya, yang sering dikenal dengan istilah Moderasi Islam atau wasathiyah. Pada prinsipnya, Islam selalu memadukan kedua titik ekstrimitas yang saling berlawanan. Sebagai contoh, ajaran Islam tidak semata memuat persoalan ketuhanan secara esoterik, melainkan juga hal-hal lain menyangkut kemanusiaan dengan implikasinya dalam kehidupan sehari-hari(Abu Yasid, 2014: 7). Umat Islam merupakan ummat pertengahan, moderat dan teladan dalam melangsungkan kehidupan di tengah keragaman. Untuk menanggulangi gerakan yang terjadi di kampus baik itu ideology khilafah dan ideology lain yang bertentangan dengan nilai-nilai Pancasila, maka peran dosen PPKn dan civitas akademik lain menempati posisi yang sangat penting.

Langkah yang harus segera dilakukan untuk meminimalisir gerakan ideology tersebut agar tidak berkembang lebih luas meliputi:

\section{a. Bersinergi antara dosen PPKn dengan dosen agama.}

Matakuliah Pendidikan Pancasila, kewarganegaraan, bahasa dan Agama merupakan mata kuliah wajib umum berdasarkan kurikulum inti yang ada di perguruan tinggi. MKWU merupakan mata kuliah kepribadian yang harus diajarkan dengan harapan Mahasiswa memiliki nilai-nilai kepribadian seperti kesopanan, ketekunan, religious, cinta tanah air, bertaqwa, kebangsaan dan berkepribadian Pancasila. Dalam implementasinya proses perkuliahan MKWU kurang bersinergi terutama anatara dosen agama dan PPKn. Masing- 
masing mempunya tujuan pembelajaran yang dipandang berbeda yang satu mengajarkan ideology Pancasila dan dosen agama mengajarkan ideology agama. Prasangka dan kondisi seperti ini kalau tidak segera diatasi akan menjadi preseden buruk bagi pendidikan Pancasila dan Kondisi berbangsa dan bernegara.

\section{b. Integrasi Materi PPKn dan Agama.}

Pendidikan Pancasila dan kewarganegaran serta Agama disebut mata kuliah kepribadian atau karakter yang sangat penting dalam menciptakan generasi bangsa Indonesia yang berkepribadian baik. Dalam prosesnya, mata kuliah ini harus diajarkan kepada Mahasiswa dengan mengintegrasikan materi pelajaran dalam setiap perkuliahannya. Menyisipkan materi pelajaran yang dilakukan oleh masing-masing dosen akan dipandang efektif untuk membangun Mahasiswa yang kepribadian baik. Nilai-nilai Universal Pancasila dalam proses pembelajarannya diintegrasikan dengan nilai-nilai agama. Pembelajaran PPKn, seperti nilai ketuhanan, kemanusiaan, persatuan, musyawarah dan keadilan akan jauh bermakna ketika diintegrasikan dengan pendekatan Agama. Integrasi pendidikan nilai adalah proses memadukan nilai-nilai tetentu terhadap sebuah konsep lain sehingga menjadi suatu kesatuan yang koheren dan tidak bisa dipisahkan atau proses pembauran hingga menjadi satu kesatuan yang utuh dan bulat. Dalam proses pembelajaran di kelas, pengembangan nilai/karakter dapat dilaksanakan dengan menggunakan pendekatan terintegrasi dalam semua mata pelajaran (embeded approach). (Suranto Aw, 2014: 230).

\section{c. Meningkatkan Kompetensi Profesional Dosen PPKn.}

Dosen Pendidikan Pancasila dan Kewarganegaraan harus membangun kemampuan untuk memahami isu-isu yang berkembang di masyarakat. Kemampuan untuk menangkap isu yang berkembang di masyarakat terutama yang disinyalir dapat mengancam ideology Pancasila. Kemampuan tersebut diimplementasikan dengan cara membangun kerangka berfikir di kelas dengan mengajak Mahasiswa untuk mendiskusikannya. Dosen yang professional akan menumbuhkan potensi berfikir Mahasiswa terhadap isu-isu yang ada misalnya ideology khilafah. Dosen PPKn akan membawa isu tersebut dengan meminta pandangan Mahasiswa dan sekaligus menjelaskan konsep yang sebenarnya. Kompetensi professional dosen dapat menjelaskan kepada Mahasiswa tentang isu-isu yang berkembang di masyarakat sehingga Mahasiswa tercerahkan dan memahami maksud dan kedudukan isu yang dimaksud. Mahasiswa tidak akan mencari sendiri tentang maksud ideology khilafah karena dalam pembelajaran pendidikan PKn isu tersebut telah mendapat penejelasan di kelas melalui metode pembelajaran studi kasus dan simulasi social.

\section{Kesimpulan dan Saran}

Dosen adalah pendidik professional yang menempati posisi strategis di dalam proses pembelajaran di perguruan tinggi. Dosen bertugas untuk mentrasformasikan ilmu pengetahuan, meneliti, mengembangkan dan mengabdikan ilmunya untuk kepentingan masyarakat. Peran Dosen Pancasila dan kewarganegaraan harus dapar menumbuhkan dan membangun karakter Mahasiswa yang berkepribadian Pancasila dalam segala aspeknya baik pandangan, pemikiran, sikap dan prilaku kehidupannya. Dalam proses pembelajarannya, dosen Pancasila dan PKN harus bersinergi dengan dosen Agama seiring dengan munculnya paham radikal di kalangan Mahasiswa yang mengatasnamakan Agama. Adanya indikasi Mahasiswa yang terpapar ideology khilafah, radikalisme dan fundamentalisme merupakan tantangan tersendiri dalam proses pembelajaran pendidikan Pancasila dan kewarganegaraan. Doosen Pancasila harus memiliki kemampuan menggunakan pendekatan agama dalam proses kegiatan belajar mengajarnya. 
Melalui model pembelajaran integrasi materi Pancasila, PKN dan moderasi Agama diharapkan dapat menanggulangi gerakan pemikiran dan ideologi khilafah yang berkembang di kampus.

\section{Daftar Pustaka}

Abdul Halim, Berchah Pitoewas, Hermi Yanzi , Ana Mentari, (2019), URGENSI MATA KULIAH UMUM PENDIDIKAN PANCASILA DALAM MENANAMKAN NILAI MORAL BUDAYA BANGSA PADA MAHASISWA MEMASUKI ERA REVOLUSI INDUSTRI 4.0, P R OS I D I N GS E I NAR N A I ONALPENDIDIKAN $F K I P U N$ I L A 201 9, FAKULTAS KEGURUAN DAN ILMU PENDIDIKAN UNIVERSITAS LAMPUNG.

Achmad Habibullah, (2012), KOMPETENSI PEDAGOGIK GURU, Jurnal EDUKASI, Volume 10, Nomor 3, September-Desember 2012, 362-377.

Ainur Rofiq Al-Amin, (2012), Membongkar Proyek Khilafah Ala Hizbut Tahrir di Indonesia, Yogyakarta: LKIS,117.

Ambiro Puji Asmaroini, (2017), MENJAGA EKSISTENSI PANCASILA DAN PENERAPANNYA BAGI MASYARAKAT DI ERA GLOBALISASI, PK: Jurnal Pancasila dan Kewarganegaraan, Vol. 2, No. 1, Januari 2017 E-ISSN 2527-7057, PISSN 2545-2683, 50-64.

Arvi Riwahyudin, (2015), PENGARUH SIKAP SISWA DAN MINAT BELAJAR SISWA TERHADAP HASIL BELAJAR IPA SISWA KELAS V SEKOLAH DASAR DI KABUPATEN LAMANDAU, JURNAL PENDIDIKAN DASAR, Volume 6 Edisi 1 Mei 2015, 7-29.

Baidhowi, (2016), "Khilafah dalam Konteks Negara Pancasila", Jurnal Seminar Nasional Hukum,

Vol. 2, No. 1, (2016), 499.

Didi Supriadie, dkk, (2012), Komunikasi Pembelajaran, Bandung: PT Remaja Rosdakarya, 11.

Donny Ermawan T, (2017), Pengaruh Globalisasi terhadap Eksistensi Kebudayaan Daerah di Indonesia, Jurnal Kajian Lemhannas RI | Edisi 32 | desember 2017, 1-56.

Friska Octavia Rosa, tth EKSPLORASI KEMAMPUAN KOGNITIF SISWA TERHADAP KEMAMPUAN MEMPREDIKSI, MENGOBSERVASI DAN MENJELASKAN DITINJAU DARI GENDER, Jurnal Pendidikan Fisika Universitas Muhammadiyah Metro, 111-118

Husaini, (2017), Pengaruh Profesional Dosen Terhadap Kualitas Pembelajaran Dosen Agama Islam Di Fakultas Keguruan Ilmu Pendidikan Universitas Pattimura, PEMBELAJAR: Jurnal Ilmu Pendidikan, Keguruan, dan Pembelajaran Volume 1 Nomor 1, 9-16. 
Indra Utama Tanjung, (2018), "Studi Komparative Pendirian Negara Khilafah di Indonesia", Jurnal Penelitian Medan Agama, Vol. 9, No. 1, (2018), 116.

Komaruddin Hidayat,(2012), Kontroversi Khilafah; Islam, Negara, dan Pancasila, Bandung: Mizan, 19.

Mochamad Hatip, Khoiriyah, dan Abadi Sanosra, Nurul Qomariah, (2018), KOMPETENSI DOSEN, PROFESIONALISME DOSEN, DAN KECERDASAN SPRITUAL DAMPAKNYA TERHADAP MOTIVASI BELAJAR MAHASISWA, JSMBI ( Jurnal Sains Manajemen Dan Bisnis Indonesia ), Vol. 8 No. 1 Juni Hal. 112-130 2018

Mohammad Mahfud MD, (2017), Pancasila Dalam Pusaran Globalisasi, Yogyakarta: LKiS, 138

Muhammad Rikza Muqtada, (2018), "Hadis Khilafah dan Relasinya Terhadap Kontestasi Politik Hizbut Tahrir Indonesia (HTI) Pasca-Perpu Nomor 2 Tahun 2017”, Mutawatir: Jurnal Keilmuan Tafsir Hadis, Vol. 8, No. 1, (Juni 2018), 4.

Nilda Hayati,(2017), “Konsep Khilafah Islamiyyah Hizbut Tahrir Indonesia; Kajian Living Al-Qur'an Perspektif Komunikasi”, Jurnal Episteme, Vol. 12, No. 1, (Juni 2017), 181182.

Riskan Qadar, (2015), MENGAKSES ASPEK AFEKTIF DAN KOGNITIF PADA PEMBELAJARAN OPTIKA DENGAN PENDEKATAN DEMONSTRASI INTERAKTIF, JURNAL INOVASI DAN PEMBELAJARAN FISIKA, VOLUME 2, NOMOR 1, MEI 2015, 1-11

Shulhan Alfinnas, (2018), ARAH BARU PENDIDIKAN ISLAM DI ERA DIGITAL, FIKROTUNA: Jurnal Pendidikan dan Manajemen Islam, Volume 7, Nomor 1, 803-817.

Suranto Aw, (2014), INTEGRASI PENDIDIKAN KARAKTER DALAM PEMBELAJARAN MATA KULIAH KOMUNIKASI INTERPERSONAL, Jurnal Pendidikan Karakter, Tahun IV, Nomor 3, Oktober 2014, 225-234.

Yuli Alama, (2017), Kompetensi Dosen, Motivasi Belajar Mahasiswa dan Dampaknya terhadap Prestasi Mahasiswa dalam Pembelajaran Pengantar Ekonomi (studi pada mahasiswa program studi Manajemen Informatika AMIK Bina Sriwijaya Palembang), Jurnal Manajemen dan Bisnis Sriwijaya (JMBS) | ISSN: 1412-4521 Vol.15 No.4 2017, 23-30.

Yuli Alama, (2018), Kompetensi Dosen, Motivasi Belajar Mahasiswa dan Dampaknya terhadap Prestasi Mahasiswa dalam Pembelajaran Pengantar Ekonomi (studi pada mahasiswa program studi Manajemen Informatika AMIK Bina Sriwijaya Palembang), Jurnal Manajemen dan Bisnis Sriwijaya Vol.16 (1), ISSN: 1412-4521, 45.|

Zuly Qodir, (2016), Kaum Muda, Intoleransi, dan Radikalisme Agama, JURNAL STUDI PEMUDA , VOL. 5 , NO. 1 , MEI 2016, 429-445. 